\title{
BIOMASS PRODUCTION OF SELECTED GRASSLAND, WETLAND AND CROPLAND VEGETATION COMMUNITIES
}

\author{
HAKROVÁ, P. ${ }^{1}$ - KŘOVÁKOVÁ, K. ${ }^{1,2} *$ - NOVOTNÁ, K. ${ }^{1}$ - VINCIKOVÁ, H. ${ }^{1}$ - ProchÁZKA, J. \\ ${ }^{1}$ Laboratory of Applied Ecology, Faculty of Agriculture, University of South Bohemia in České \\ Budějovice \\ Studentská 13, 37005 České Budějovice, Czech Republic \\ (phone: +420-387772738; fax: +420-389032520) \\ ${ }^{2}$ Department of Applied Ecology, Faculty of Environmental Sciences, Czech University of Life \\ Sciences Prague \\ Kamýcká 129, 16521 Praha 6-Suchdol, Czech Republic \\ *Corresponding author \\ e-mail: cariadwr@gmail.com
}

(Received 22 ${ }^{\text {nd }}$ Aug 2014; accepted 29 $9^{\text {th }}$ Oct 2014)

\begin{abstract}
Biomass production is a generally well-studied phenomenon but it often only focuses on simple habitats such as monodominant wetland communities. Information on aboveground biomass production of various managed and unmanaged communities was necessary for a research project called the "Minimization of Radioactive Contamination Impacts on the Landscape in the Emergency Planning Zone of the Temelín Nuclear Power Plant" to create growth models of selected plant communities to estimate the amount of biomass potentially contaminated by radiation in case of a nuclear power plant accident. In the present paper we introduce the results of biomass sampling carried out in the vegetation season of 2013 and compare it with the previously published data. Especially the curve shapes could be well compared where the relevant data was found in literature, namely in the case of monodominant wetland communities. In cases where the data on seasonal production was not available (e.g. Filipendula stands) the peak values were compared and found to correspond well, too. There was no relevant published data to be found for 9 stand types (some rich-in-species grasslands and crops); together with detailed description of the sampled stands the original data on the aboveground biomass production is published for the first time.
\end{abstract}

Keywords: production curves; grassland stands; wetland stands; arable croplands

\section{Introduction}

Primary production of plant biomass is a crucial basis for other ecosystem processes. It is strongly related to the flow of matter through an ecosystem (Mooney, 1991) and thus plays a key role in landscape functions (Wiegand et al., 2004). Besides the physiology of plants forming a plant community and their ecologic strategies biomass production is significantly influenced by environmental factors such as climate and microclimate and the resulting water supply (Palmer and Yunusa, 2011), soil properties, especially the nutrient regime (Č́ízková et al., 2001) and pressure from the herbivores (Moise and Henry, 2012) or - in case of agricultural ecosystems - an extra supply of nutrients, harvest and other farming practices (Heggenstaller et al., 2009).

The methods to determine biomass production can be generally divided into destructive and non-destructive types. Belowground (root) biomass is usually determined by destructive methods such as monoliths (dug samples) or sampling tubes where the soil is subsequently washed out (Dykyjová, 1989; Rychnovská, 1987). Destructive sampling of aboveground biomass is based on the removal of plants from a square plot of a precisely defined surface (for grass communities it is generally between 
0,25 x 0,25 and 1 x 1 m, cf. Dykyjová, 1989; Rychnovská, 1987). With helophytes, which often tend to form clusters, the sampling plots have to be larger than the average clusters (Ondok and Dykyjová, 1973; Ondok and Květ, 1978). Sampling plots can be distributed either randomly on the site, which requires more samples to capture the differences in plant size or density in various conditions (especially when it comes to nutrients and water availability). The second approach uses sample plots located at transects along the ecological gradients; this method is more advantageous as it requires less sampling plots.

Non-destructive methods - or rather a combination of both approaches - are based on the estimation of the aboveground biomass counting the number of stalks and/or plant leaves in a sampling plot, and multiplying it by the average weight of the relevant plant parts harvested from the neighbouring plants outside the plot (Ondok and Květ, 1978; Květ and Westlake, 1998). If the plots are held as permanent and the outside harvest is carried out in regular (usually monthly) intervals, the seasonal dynamics of biomass production can be observed (Ondok and Dykyjová, 1973).

There are also indirect methods to estimate the biomass production. One of the indices describing both the plant productivity and biogeochemical fluxes between vegetation and the atmosphere is the leaf area index (LAI) (Bréda, 2003). Together with the above described in-situ biomass sampling it is also often a subject of remote-sensing based estimations of biomass production in the landscape (Na et al., 2003; Cook et al., 2009) or the global scale.

The biomass production values can be obtained in various forms depending on the aim of the study, selected method and other circumstances influencing the experimental design. The biomass amount can be expressed as peak (i.e. the maximum) value or total (sum) value of the biomass produced by a plant community throughout the growing season (Scurlock et al., 2002). The seasonal variability of biomass production and its dynamics can be observed using growth models (e.g. Rosef and Bonesmo, 2005), which requires regular harvest of accumulated biomass during the growing season.

Biomass production and plant productivity were initially studied as a part of an overall ecological research of selected important biotopes. A broad research on productivity of terrestrial, freshwater and marine biotopes was launched as one of the chapters of the International biological program (IBP). A great amount of measurements of biomass production and productivity, vegetation density, LAI and other indicators (such as shoot length, inflorescence number, etc.) of both individual species and communities was gathered in the Czech Republic under this research project (cf. e.g. Hejný et al., 1970; Rychnovská, 1972; or Dykyjová and Květ, 1978). The campaign of such an extent and aim is rather unimaginable nowadays: biomass production is studied as a component of crop yield (Heggenstaller, 2009), an indicator of the plant potential as an energetic source (Bentsen et al., 2014) or a carbon sink (Aosaar et al., 2013).

The data on biomass production presented in this paper were collected in order to create the growth models of selected plant communities to estimate the amount of biomass potentially contaminated by radiation in case of a nuclear power plant accident (Brom et al., 2013); the actual amount of contaminated biomass which would be necessary to harvest, transport and decontaminate or safely store and its spatial distribution are some of the key parameters to design later phases of emergency planning aimed at landscape decontamination. As one of the objectives of the research project "Minimization of Radioactive Contamination Impacts on the Landscape in the Emergency Planning Zone of the Temelín Nuclear Power Plant" the grassland, wetland 
and crop vegetation communities at selected sites located in the Emergency Planning Zone of the Temelín Power Plant (south of the Czech Republic) were measured during the growing season 2013 in suitable intervals. There are a few studies covering this diversity of biotopes and presenting the primary values. The preliminary results of the aboveground biomass productivity of the studied biotopes are also compared with the relevant values obtained through a literature review.

\section{Methods}

\section{Selection of permanent sample plots for aboveground biomass sampling}

Preliminary plot selection was restricted to three model catchments of Žimutice, Knín and Krč (Fig. 1) located in the Temelín Nuclear Power Plant Emergency Planning Zone; it was based on the screening of the Natura 2000 maps and Land Parcel Identification System (LPIS) database. The final selection of the plots was done during the field survey in March 2013.

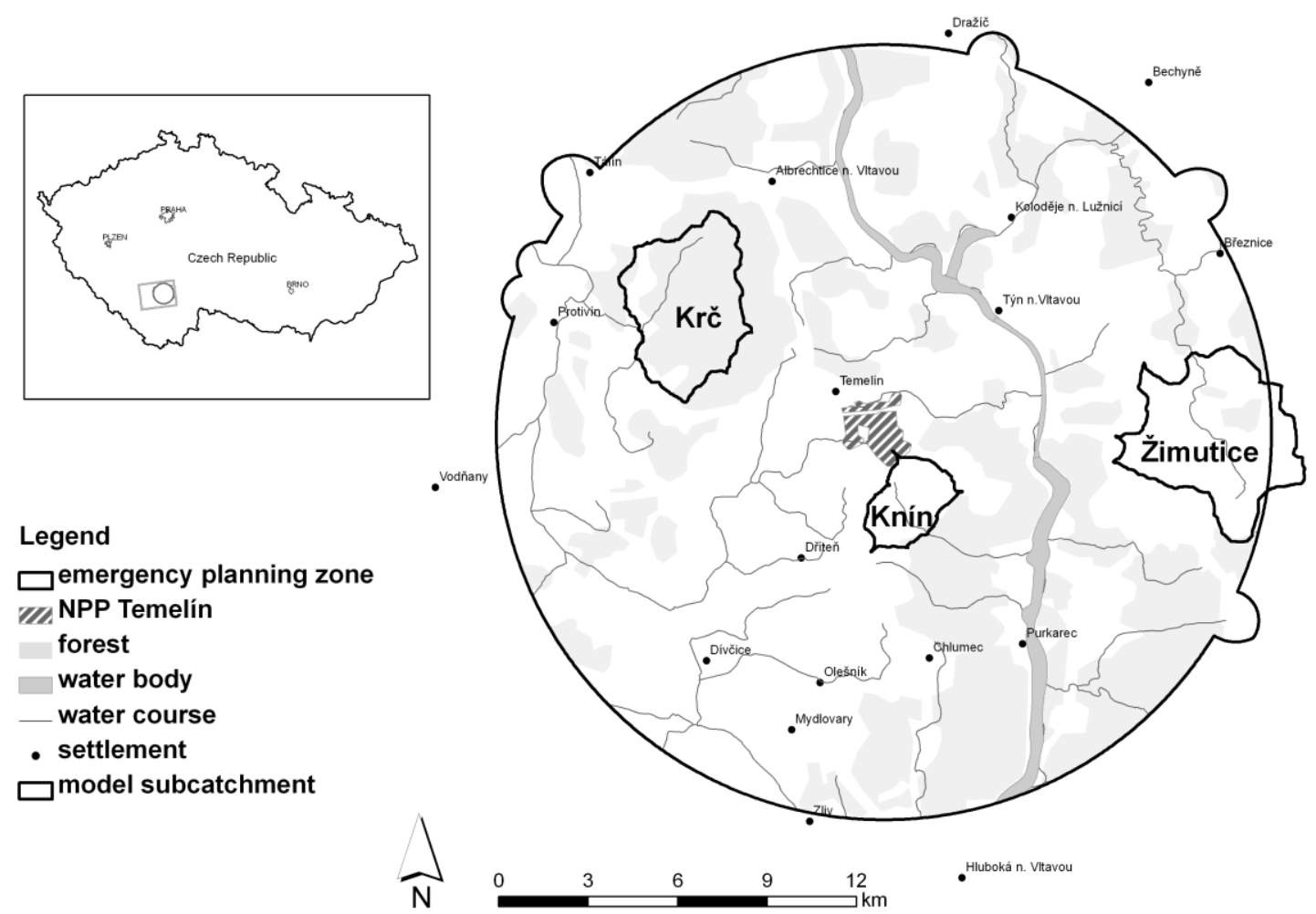

Figure 1. Localization of the model catchments in Emergency planning zone of NPP Temelin and position of the zone in Czech Republic. The sampling sites of Filip-1, Cirs-2, Allop-3, ReedT-4, Oilseed-5, WheatW-6, WheatS-7, IntensM-8 and Maize-21 are situated in the Žimutice catchment, the ReedL-9, Glyc-10, Typha-11 and Carex-12 belong to the Knin catchment, and Filip-13, Typha-14, Carex-15, Cirs-16, Glyc-17, Allop-18, ReedT-19 and Arrhen-20 to the Krč catchment.

The overall climatic parameters of the studied area during the 2013 vegetation season are given on Fig. 2. 


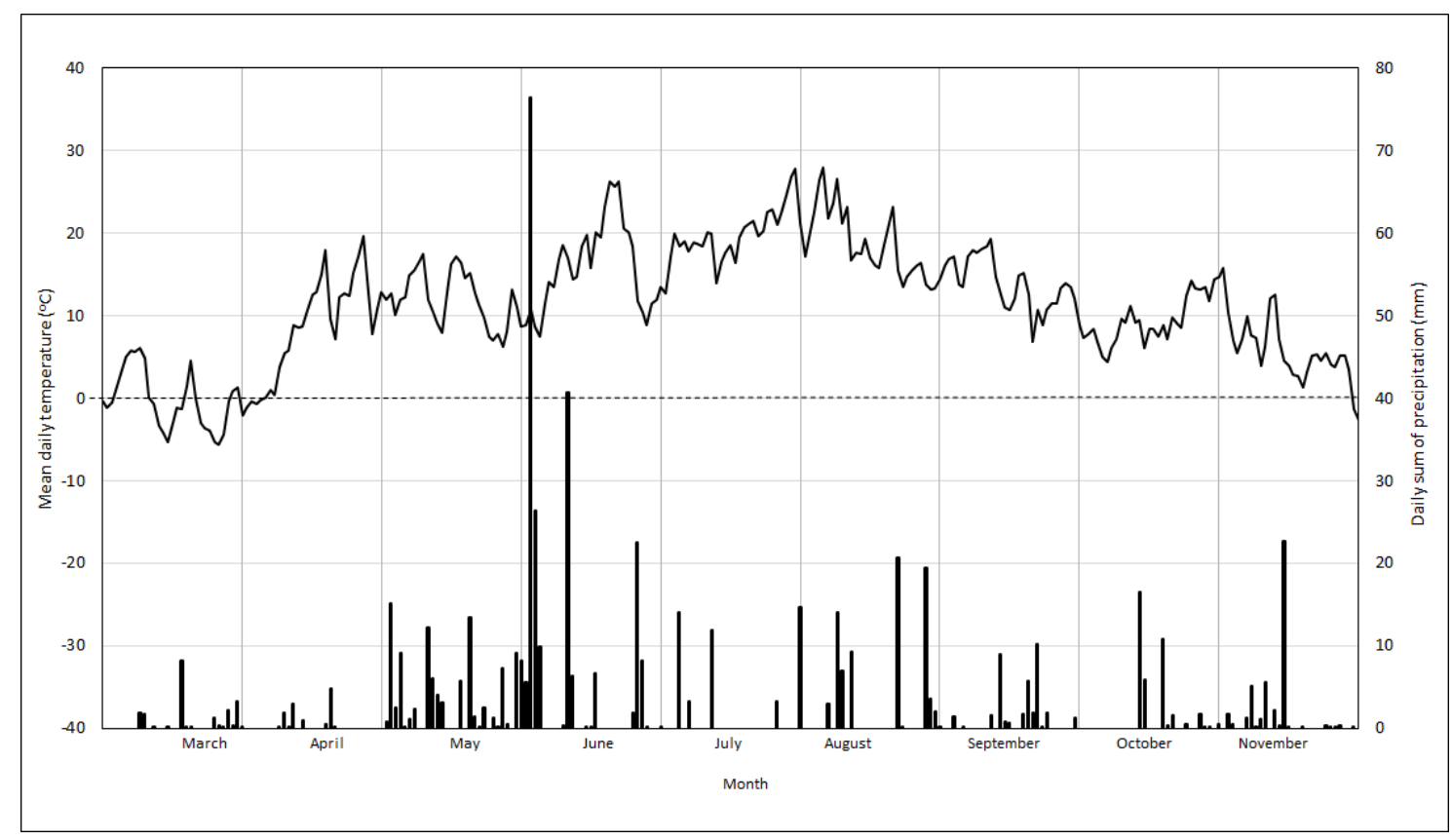

Figure 2. Daily sum of precipitation (columns) and mean daily temperatures (curve) in the Emergency planning zone area in the vegetation season of 2013 (source: Czech Hydrometeorological Institute)

21 vegetation stands in total were selected covering a wide variety of natural conditions (from freshwater to terrestrial biotopes) and types of land use (agricultural arable and grassland stands and non-agricultural semi-natural and natural non-forest vegetation). Agricultural crops were sampled on a one-plot-per-crop basis given their low production variability. Four crop species were selected covering the largest area of the arable land in the Emergency Planning Zone, i.e. winter crop (the "WheatW-6" sampling site), spring crop ("WheatS-7"), oilseed rape ("Oilseed-5") and maize ("Maize-21").

The grassland stands were sampled along the gradient from a dry to wet grassland. The sample sites were selected to cover each wetness level by two stands (e.g. dry grasslands are represented by the "Intensively managed meadows"1 ["IntensM-8"] and the "Mesic Arhenatherum meadows" ["Arhen-20"]). Pairs of the sites are also situated to cover the "agricultural" (Žimutice and Knín) and "natural" (Krč) model catchments.

In the present work we studied unmanaged stands such as the "Wet Filipendula grassland" ("Filip-1", "Filip-13") and "Wet Cirsium meadow" ("Cirs-16") which was not mowed. The managed stands were represented by a mowed "Wet Cirsium meadow" ("Cirs-2"), "Alluvial Alopecurus meadow" ("Alop-3", “Alop-18"), "Mesic Arrhenatherum meadow" ("Arrhen-20") and "Intensively managed meadow" ("IntensM-8"). All these meadows were mowed twice in the observed period, and the "IntensM-8" was even cropped in the autumn.

Natural and semi-natural grassland communities were represented by the "Wet Cirsium meadows", T1.5 ("Cirs-16"), "Wet Filipendula grasslands", T1.6 ("Filip-1", "Filip-13"), "Tall-sedge beds", M1.7 ("Carex-12", "Carex-15”) and "Reed beds of

\footnotetext{
${ }^{1}$ The nomenclature and codes of the vegetation stands follow the Habitat catalogue of the Czech Republic (Chytrý et al., 2010), designed for the NATURA 2000 habitat mapping.
} 
eutrophic still waters", M1.1 ("ReedT-4", "ReedL-9", “Glyc-10", "Typha-11”, “Typha14", "Glyc-17", "ReedT-19"). A short description of the communities both according to Chytrý et al. (2010) and our relevés performed on the studied habitats together with type of management of the sites is given in the following text and in Tab. 1 .

Table 1.Management type and phytocenologic characteristic of the sampled stands.M, J, Scover (in percent) and number of species in May, July and September.Ratio (G:L:F) proportion of grasses, legumes and herbaceous plants; the grasses group besides the Poaceae grasses involves also Cyperaceae, Juncaceae and Typhaceae. The percentage at the individual species represents the average cover calculated from all the three relevés.

Diagnostic species are listed after Chytrý et al.(2010).

\begin{tabular}{|c|c|c|c|c|c|c|c|}
\hline & Management & $\begin{array}{l}\text { Cover } \\
\text { (M, J, S, \%) }\end{array}$ & $\begin{array}{l}\text { Number } \\
\text { species } \\
(\mathbf{M}, \mathrm{J}, \mathrm{S})\end{array}$ & $\begin{array}{l}\text { Ratio } \\
\text { G:L:F }\end{array}$ & $\begin{array}{l}\text { Dominant species } \\
(\%)\end{array}$ & $\begin{array}{l}\text { Species with cover } \\
\text { higher than } 5 \%\end{array}$ & Diagnostic species (\%) \\
\hline ReedL-9 & unmanaged & $30,97.5,90$ & $1,2,1$ & $1: 0: 1$ & $\begin{array}{l}\text { Phragmites australis } \\
\text { (72.3) }\end{array}$ & & Phragmites australis (72.3) \\
\hline ReedT-4 & unmanaged & $10,51,95$ & $1,3,1$ & $1: 0: 2$ & $\begin{array}{l}\text { Phragmites australis } \\
\text { (51.7) }\end{array}$ & & Phragmites australis $(51.7)$, Solanum dulcamara $(0.2)$ \\
\hline ReedT-19 & unmanaged & $17.8,97.2,96.6$ & $9,7,9$ & 3:0:9 & $\begin{array}{l}\text { Phragmites australis } \\
\text { (68.3) }\end{array}$ & & Phragmites australis $(68.3)$, Equisetumfluviatile $(0.2)$ \\
\hline Typha-11 & unmanaged & $12,46.5,41.5$ & $3,5,4$ & $3: 0: 2$ & $\begin{array}{l}\text { Typha angustifolia } \\
(29.3)\end{array}$ & & $\begin{array}{l}\text { Typha angustifolia (29.3), Glyceria maxima (2.5), Typha } \\
\text { latifolia (1) }\end{array}$ \\
\hline Typha-14 & unmanaged & $71.3,65.9,70.8$ & $7,6,5$ & $3: 0: 5$ & $\begin{array}{l}\text { Typha angustifolia } \\
(48.3)\end{array}$ & Lemna minor (20) & $\begin{array}{l}\text { Typha angustifolia (48.3), Typha latifolia }(0.5), \text { Equisetum } \\
\text { fluviatile }(0.2)\end{array}$ \\
\hline Glyc-10 & unmanaged & $70.5,80.5,70.5$ & $2,3,2$ & 2:0:1 & $\begin{array}{l}\text { Glyceria maxima } \\
(72.7)\end{array}$ & & Glyceria maxima (72.7), Phragmites australis (1) \\
\hline Glyc-17 & unmanaged & $65.9,78.5,90$ & $9,8,7$ & $3: 0: 9$ & Glyceria maxima (74) & & Glyceria maxima $(74)$ \\
\hline Carex-12 & unmanaged & $31,90.5,76$ & $2,3,4$ & $3: 0: 2$ & Carexacuta $(62.7)$ & & $\begin{array}{l}\text { Carex acuta }(62.7) \text {, Phalaris arundinacea }(0.2) \text {, Lysimachia } \\
\text { vulgaris }(0.2)\end{array}$ \\
\hline Carex-15 & unmanaged & $92,83,86.1$ & $\begin{array}{l}10,12, \\
11\end{array}$ & $5: 1: 10$ & Carex acuta $(68.3)$ & $\begin{array}{l}\text { Phalaris } \\
\text { arundinacea (15) }\end{array}$ & $\begin{array}{l}\text { Carex acuta }(68.3) \text {, Phalaris arundinacea }(15) \text {, Lysimachia } \\
\text { vulgaris }(0.5) \text {, Lythrum salicaria }(0.3) \text {, Galium palustra } \\
(0.3), \text { Peucedanum palustre }(0.1)\end{array}$ \\
\hline Filip-1 & unmanaged & $92,95.5,89$ & $11,9,7$ & 4:0:8 & $\begin{array}{l}\text { Filipendula ulmaria } \\
(83.3)\end{array}$ & & $\begin{array}{l}\text { Filipendula ulmaria }(83.3) \text {, Caltha palustris }(0.8) \text {, Scirpus } \\
\text { sylvaticus }(0.8), \text { Lysimachia vulgaris }(0.5), \text { Alopecurus } \\
\text { pratensis }(0.3)\end{array}$ \\
\hline Filip-13 & unmanaged & $76.2,89,95.5$ & $7,5,4$ & $1: 0: 7$ & $\begin{array}{l}\text { Filipendula ulmaria } \\
(56.7)\end{array}$ & $\begin{array}{l}\text { Phalaris } \\
\text { arundinacea }(18.3), \\
\text { Urtica dioica }(9.3)\end{array}$ & Filipendula ulmaria (56.7), Caltha palustris (1.8) \\
\hline Cirs-16 & unmanaged & $71,92.2,91.2$ & $\begin{array}{l}18,18, \\
19\end{array}$ & $7: 1: 15$ & $\begin{array}{l}\text { Scirpus sylvaticus } \\
(46.7)\end{array}$ & $\begin{array}{l}\text { Phalaris } \\
\text { arundinacea }(10), \\
\text { Glyceria maxima } \\
(8.3)\end{array}$ & $\begin{array}{l}\text { Scirpus sylvaticus }(46.7) \text {, Carex nigra }(2.3) \text {, Deschampsia } \\
\text { cespitosa }(2.2) \text {, Cirsium palustre }(1) \text {, Caltha palustris }(0.5) \text {, } \\
\text { Sanquisorba officinalis }(0.4) \text {, Galium palustre }(0.3), \\
\text { Lathyrus pratensis }(0.3), \text { Poa trivialis }(0.2), \text { Juncus } \\
\text { conglomeratus }(0.2)\end{array}$ \\
\hline Cirs-2 & mowing & $92.5,87,52.5$ & $17,15,8$ & 7:3:14 & $\begin{array}{l}\text { Scirpus sylvaticus } \\
(36.7)\end{array}$ & Poa trivialis (28.3) & 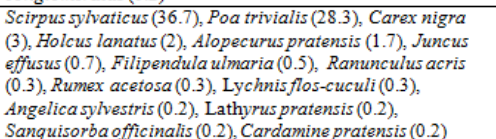 \\
\hline Allop-3 & mowing & $94,65.5,69.5$ & $\begin{array}{l}18,17, \\
16\end{array}$ & $10: 2: 12$ & Poatrivialis (35) & $\begin{array}{l}\text { Ranunculus repens } \\
\text { (10), Alopecurus } \\
\text { pratensis }(6.7), \\
\text { Festuca pratensis } \\
\text { (6) }\end{array}$ & $\begin{array}{l}\text { Poa trivialis }(35) \text {, Ranunculus repens }(10) \text {, Alopecurus } \\
\text { pratensis }(6.7) \text {, Festuca pratensis }(6) \text {, Holcus lanatus }(4) \text {, } \\
\text { Ranunculus acris }(2.8) \text {, Trifolium hybridum }(2) \text {, Carex hirta } \\
(1.2) \text {, Sanquisorba officinalis }(0.5) \text {, Lychnis flos-cuculi }(0.3) \text {, } \\
\text { Cardamine pratensis }(0.2) \text {, Geranium pratense }(0.2)\end{array}$ \\
\hline Allop-18 & mowing & $74.1,78.1,88.3$ & $\begin{array}{l}25,28, \\
31\end{array}$ & $15: 3: 17$ & Festuca rubra (13.3) & $\begin{array}{l}\text { Poa trivialis }(10), \\
\text { Ranunculus repens } \\
\text { (8.3), Lathyrus } \\
\text { pratensis }(6.7), \\
\text { Alopecurs pratensis } \\
(5.8)\end{array}$ & $\begin{array}{l}\text { Poa trivialis (10), Ranunculus repens ( }(8.3) \text {, Lathyrus } \\
\text { pratensis }(6.7) \text {, Alopecurs pratensis }(5.8) \text {, Holcus lanatus } \\
\text { (4.3), Poa pratensis (4), Deschampsia cespitosa (3.3), Carex } \\
\text { hirta (3), Ranunculus acris (1.2), Lysimachia nummularia } \\
(0.5) \text {, Sanquisorba officinalis }(0.5) \text {, Lychnis flos-cuculi }(0.2) \text {, } \\
\text { Scirpus sylvaticus }(0.2) \text {, Festuca pratensis (0.2), Glechoma } \\
\text { hederacea }(0.1)\end{array}$ \\
\hline Anhen-20 & mowing & $81.1,94,79.5$ & $\begin{array}{l}23,21 \\
18\end{array}$ & $10: 4: 12$ & $\begin{array}{l}\text { Dactylis glomerata } \\
\text { (15) }\end{array}$ & $\begin{array}{l}\text { Holcus lanatus } \\
\text { (10), Poa pratensis } \\
\text { (6.7), } \\
\text { Arrhenatherum } \\
\text { elatior }(6), \\
\text { Alopecurus } \\
\text { pratensis }(6), \\
\text { Trifoliumpratense } \\
\text { (6), Festuca rubra } \\
\text { (5), }\end{array}$ & 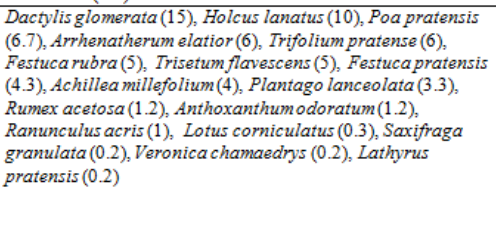 \\
\hline IntensM-8 & $\begin{array}{l}\text { mowing, } \\
\text { grazing }\end{array}$ & $100,96.5,36$ & $16,14,8$ & $7: 2: 10$ & $\begin{array}{l}\text { Taraxacum sect. } \\
\text { Ruderalia }(40)\end{array}$ & $\begin{array}{l}\text { Trifolium repens } \\
\text { (12), Trifolium } \\
\text { pratense }(8.5), \text { Poa }\end{array}$ & \\
\hline & & & & & & pratensis $(7.3)$ & \\
\hline WheatW-6 & arable land & $80.6,86,0$ & $3,3,0$ & $2: 0: 2$ & $\begin{array}{l}\text { Triticumaestivum } \\
(82.5)\end{array}$ & & \\
\hline WheatS-7 & arable land & $50.3,82.1,0$ & $4,6,0$ & $2: 0: 6$ & $\begin{array}{l}\text { Triticumaestivum } \\
(65)\end{array}$ & & \\
\hline Oilseed-5 & arable land & $98.5,99.1,0$ & $3,4,0$ & 4:0:0 & Brassica napus (97.5) & & \\
\hline Maize-21 & arable land & $5,16.6,61.5$ & $1,9,3$ & $4: 0: 6$ & Zea mays (26.7) & & \\
\hline
\end{tabular}


Reed beds of eutrophic still waters (ReedT-4, ReedL-9, Glyc-10, Typha-11, Typha-14, Glyc-17, ReedT-19)

The littoral vegetation of fishponds, dead river arms and banks of slow-moving river parts, poor in species. They are characteristically dominated by one species determining the physiognomy of the stand; the stands can reach $0,5-4 \mathrm{~m}$ in height and the adequate diverse amount of biomass (Chytrý et al., 2010). That is why the community was further classified according to the dominant species into three classes: Reed beds of eutrophic still waters with dominant Phragmites australis (ReedT-4, ReedL-9, ReedT-19), Reed beds of eutrophic still waters with dominnt Typha angustifolia and T. latifolia (Typha11, Typha-14) and Reed beds of eutrophic still waters with dominant Glyceria maxima (Glyc-10, Glyc-17).

Both the littoral and terrestrial Phragmites stands of the ReedL-9, ReedT-4 and ReedT-19 classes belong to this group. The first two stands were relatively typical in terms of their species composition (see Tab. 1), with some untypical accompanying species only present in the ReedT-19 class, although their proportion was not high. These were species belonging to the Wet Cirsium meadow, e.g. Scirpus sylvaticus, Cirsium palustre, Galium palustre, and also ruderal species (Urtica dioica).

The Glyc-10 was a typical stand of its biotope type according to Chytrý et al. (2010) (see Tab. 1). The Glyc-17 species composition was more variable with Glyceria maxima as a dominating species but there was also a small proportion of the Tall sedge bed species such as Carex rostrata, Peucedanum palustre or ruderal species (Urtica dioica, Cirsium arvense).

\section{Tall-sedge beds (Carex-12, Carex-15)}

The stands dominated by tall sedges are typically situated on littoral shallows and banks of fishponds, river arms in late stages of succession, inundated river and stream alluvia or waterlogged depressions on meadows. Frequently they adjoin the eutrophic Phragmites stands (Chytrý et al., 2010).

Carex-12 and Carex-15 were both adjacent to the littoral reed stands. The water level had been under the soil surface for most of the year, which probably led to the absence of wetland species and the dominance of some ruderal species such as the Urtica dioica and Galeopsis bifida. In other aspects both of the stands with the dominant Carex acuta and other accompanying species corresponded with the biotope classification according to Chytrý et al. (2010).

\section{Wet Filipendula grasslands (Filip-1, Filip-13)}

The community usually arises from fallow Wet Cirsium meadows; it is often a monodominant stand of Filipendula ulmaria with an admixture of other tall plants.

Whereas the Filip-1 class corresponded well with this biotope type description according to Chytrý et al. (2010), the Filip-13 stand was partially ruderalised (with the presence of the Urtica dioica, Galium aparine).

\section{Wet Cirsium meadows (Cirs-2, Cirs-16)}

Wet meadows rich in species on waterlogged gleysols in stream and smaller river alluvia or springs ranging from lowlands to mountainous areas. The groundwater level 
is permanently high. The meadows are mown once or twice a year; they rapidly change in line with the change in management.

The Cirs-16 is situated in the estuarine part of a fishpond. It is a rich-in-species stand dominated by the Scirpus sylvaticus and including 22 more species representing up to $45 \%$ (cf. Tab. XY). The stand generally corresponded with the description according to Chytrý et al. but the proportion of the species from neighbouring biotopes (e.g. the Glyceria maxima, Phalaris arundinacea and also ruderal species such as the Urtica dioica, Cirsium arvense, Galium aparine, etc.) was higher.

\section{Alluvial Alopecurus meadows (Alop-3, Alop-18)}

Fresh wet meadows in inundated areas of stream alluvia, on deep soils rich in nutrients situated from lowlands to submontane areas. These meadows were mown at least once a year.

\section{Mesic Arrhenatherum meadows (Arhen-20)}

Meadows of lowlands and hilly areas rich in species on nutrient-rich soils dominated by the Arrhenatherum elatius or submontane meadows on oligotrophic Cambisols poorer in nutrients dominated by the Agrostis capillaris and Festuca rubra. The stands were usually mown twice a year and occasionally grazed.

\section{Intensively managed meadows (IntensM-8)}

The meadows or clover/grass mixtures poor in species, well manured and occasionally ploughed. The prevailing species are grasses (Alopecurus pratensis, Dactylis glomerata) and nitrophilous broadleaf herbaceous plants (Taraxacum sect. Ruderalia, Rumex obtusifolius, Antriscus sylvestris).

The mowed meadows with their structure and proportion of diagnostic species corresponded well with the biotope description according to Chytrý et al. (2010); the IntensM-8 was a standard trefoil-grass mixture with the dominant Taraxacum Sect. Ruderalia and presence of a small proportion of many field weed species. The stand was mown twice in the 2013 season and after the second mowing it was grazed until November.

\section{Sampling of aboveground biomass}

The amount of aboveground biomass was estimated by destructive sampling from sample plots situated along the moisture-based transect (to cover the variability of the stands as much as possible) at regular $5-50 \mathrm{~m}$ distances (according to the area of the stand). Five squares comprising the surface of $0,5 \times 0,5 \mathrm{~m}$ were cut from each stand. The total of 105 plots (5 plots from each of 21 vegetation stands) was sampled during each sampling term. The biomass was cut just above the ground by garden scissors. In case of non-managed stands dead last year's shoots (i.e. at reed stands) were removed. The biomass was weighted, dried at $85^{\circ} \mathrm{C}$ and weighted again (Dykyjová, 1989; Ondok and Květ, 1978; Rychnovská, 1987). The sampling was carried out from the beginning of March to mid-November 2013 (the exact values are stated in Figs. 3 - 9 and Tab. 2). The intervals between sampling dates were chosen according to the growth intensity of the stands (the highest intensity in spring; less frequent sampling in the autumn). 11 samplings were done altogether. Relevés of all stands (Moravec et al., 1994) were done 
during the sampling carried out on the $14^{\text {th }}$ May, $16^{\text {th }}$ July and $3^{\text {rd }}$ September. One control sampling was done on the $15^{\text {th }}$ July 2014 on the WheatW-6 and Oilseed-5 sampling sites.

\section{Results}

The production values are presented both in the form of production curves (Fig. 3-9) and the average values of the individual sampling dates of all the studied stands (Tab. 2).

The Phragmites production of biomass (Fig. 3) have similar curve shapes in all the locations; the minimum values were observed on the first sampling date in April and the maximum was reached in October, whereas the maximum value of the ReedL-9 littoral stand in Knín was higher $\left(2,309 \mathrm{~g} \mathrm{DW}^{*} \mathrm{~m}^{-2}\right)$ than that of the ReedT-19 terrestrial stands in $\mathrm{Krč}^{2}\left(1,544 \mathrm{DW}^{*} \mathrm{~m}^{-2}\right)$ and the ReedT-4 stand in Žimutice $\left(1,819 \mathrm{~g} \mathrm{DW}^{*} \mathrm{~m}^{-2}\right)$. The development of the ReedT-4 and especially the ReedT-19 terrestrial stand was notably slower in springtime than that of the ReedL-9 littoral stand; the differences between the values reached up to $1,300 \mathrm{~g} \mathrm{DW}^{*} \mathrm{~m}^{-2}$ in May and June. The decline of the curves is of a different intensity - the November values drop below the spring (ReedL-9), summer (ReedT-4) or only autumn (ReedT-19) values.

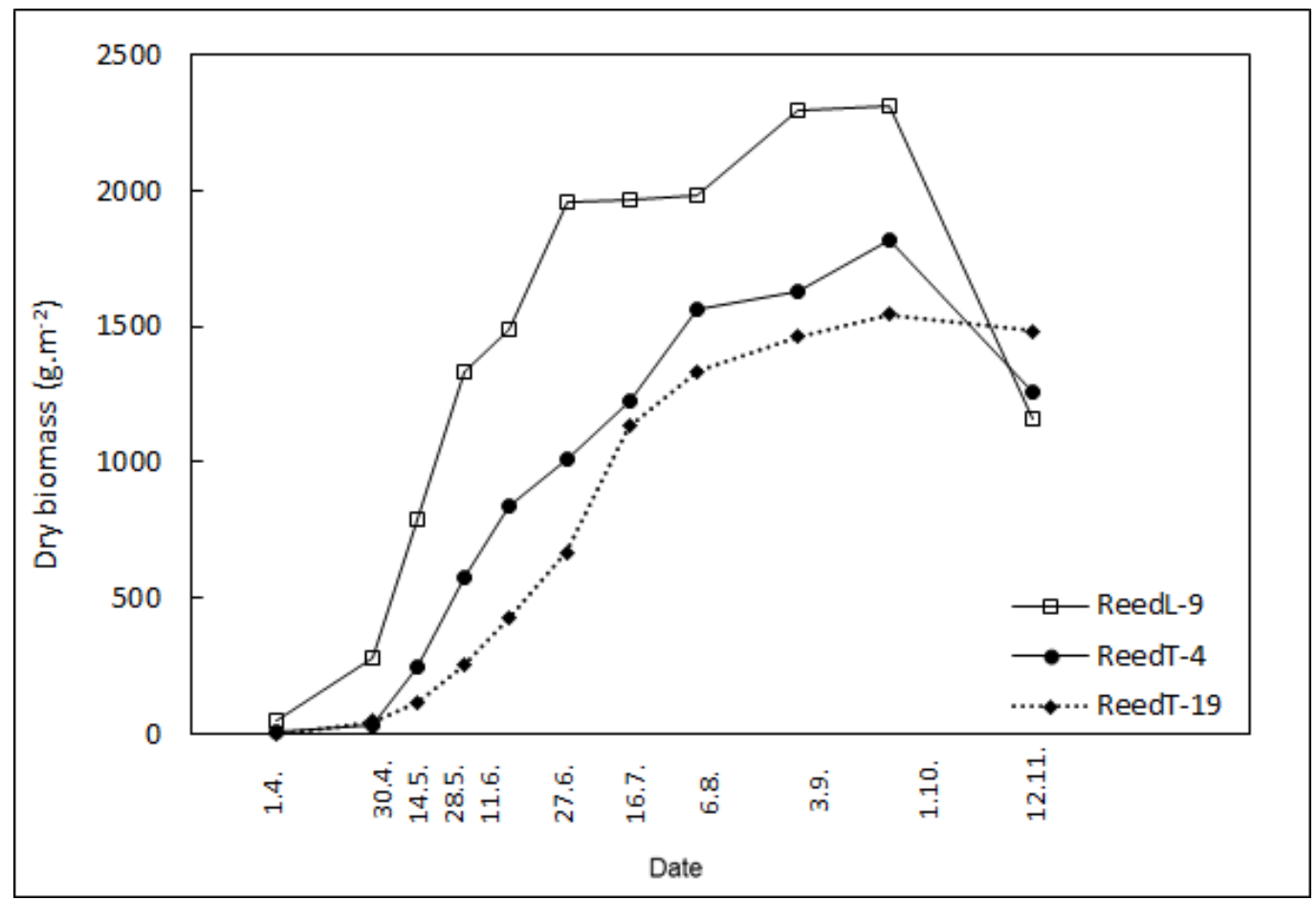

Figure 3. Dry biomass production of the Phragmites reed bed community

The Glyceria stands (Fig. 4) display a similar curve development in both locations. The Glyc-10 performed in general lower values than the Glyc-17. There is a greater difference between the maximum values at the Glyc-17 $\left(1,291 \mathrm{~g} \mathrm{DW}^{*} \mathrm{~m}^{-2}\right)$ and Glyc-10 $\left(940 \mathrm{~g} \mathrm{DW}^{*} \mathrm{~m}^{-2}\right)$, both reached in July. The Glyc-10 curve also declines faster and lower than the Glyc-17 one. 


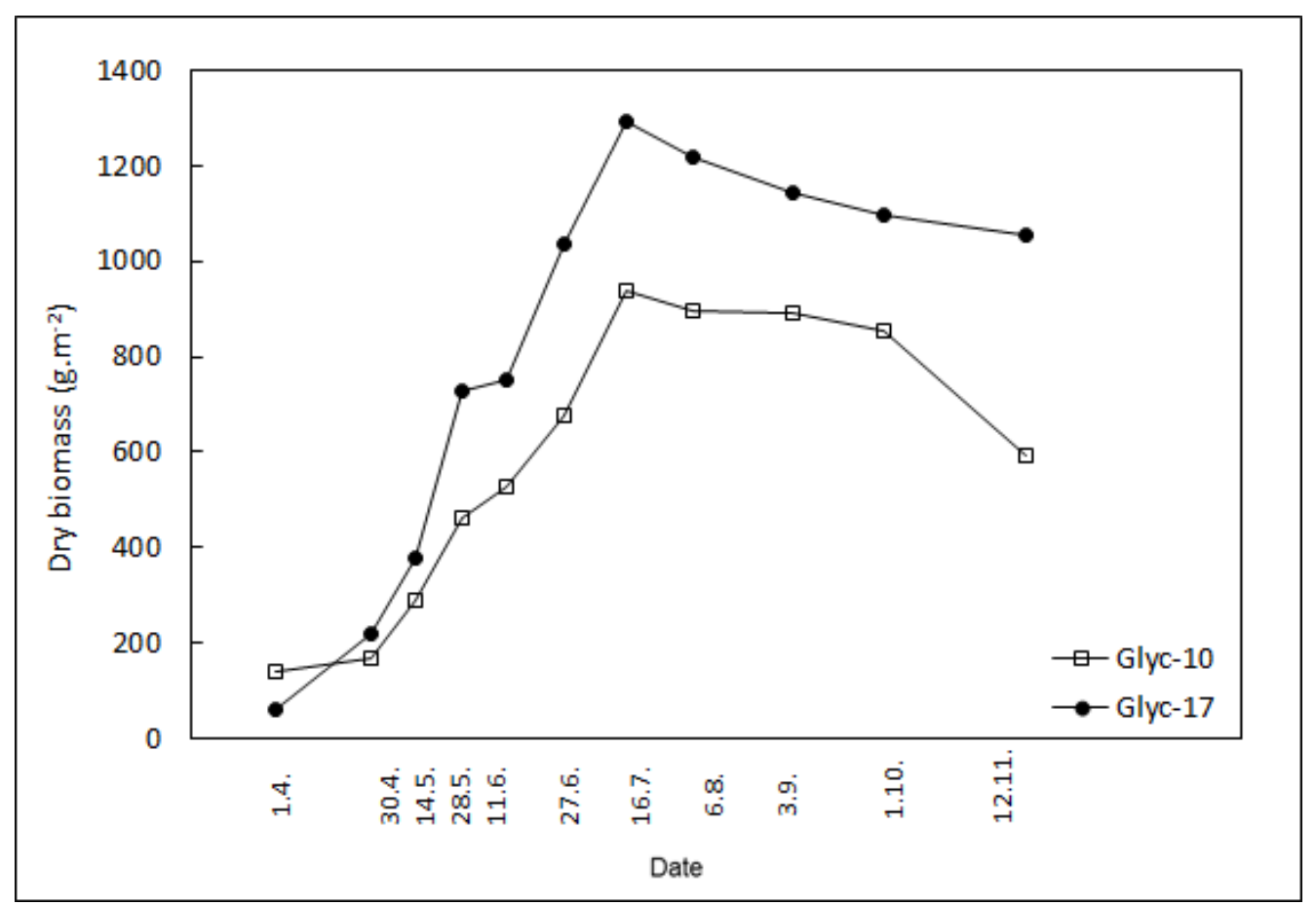

Figure 4. Dry biomass production of the Glyceria reed bed community

The curves of tall sedges stands (Fig. 5) follow a similar trend until the June sampling, when the Carex-12 stand reached its maximum $\left(970 \mathrm{~g} \mathrm{DW}^{*} \mathrm{~m}^{-2}\right)$ and then slowly declines; the Carex-15 stand, on the other hand, increases until the beginning of August and then declines fast and low. The maximum value reached was almost identical $\left(963 \mathrm{~g} \mathrm{DW}^{*} \mathrm{~m}^{-2}\right)$.

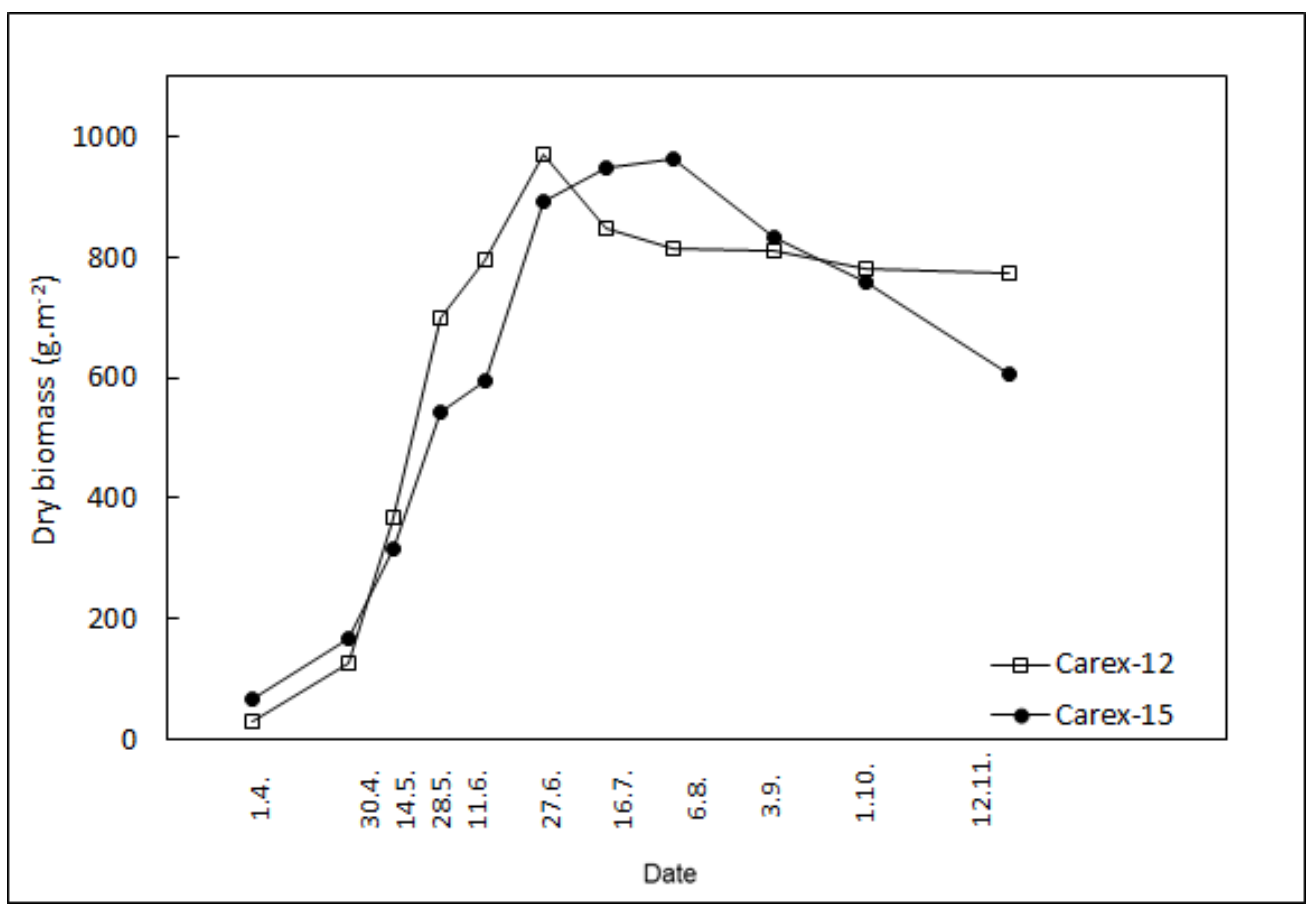

Figure 5. Dry biomass production of the Carex reed bed community 
The Typha curves (Fig. 6) have again a very similar development in both locations. Typical is a long, relatively slow increase and maximum values occurring in late September $\left(1,461 \mathrm{~g} \mathrm{DW}^{*} \mathrm{~m}^{-2}\right.$ at the Typha-11 stand, $1,129 \mathrm{~g} \mathrm{DW}^{*} \mathrm{~m}^{-2}$ at the Typha-14 stand). There is an insignificant peak at the Typha-14 stand, and the decline towards October sampling date is very slow.

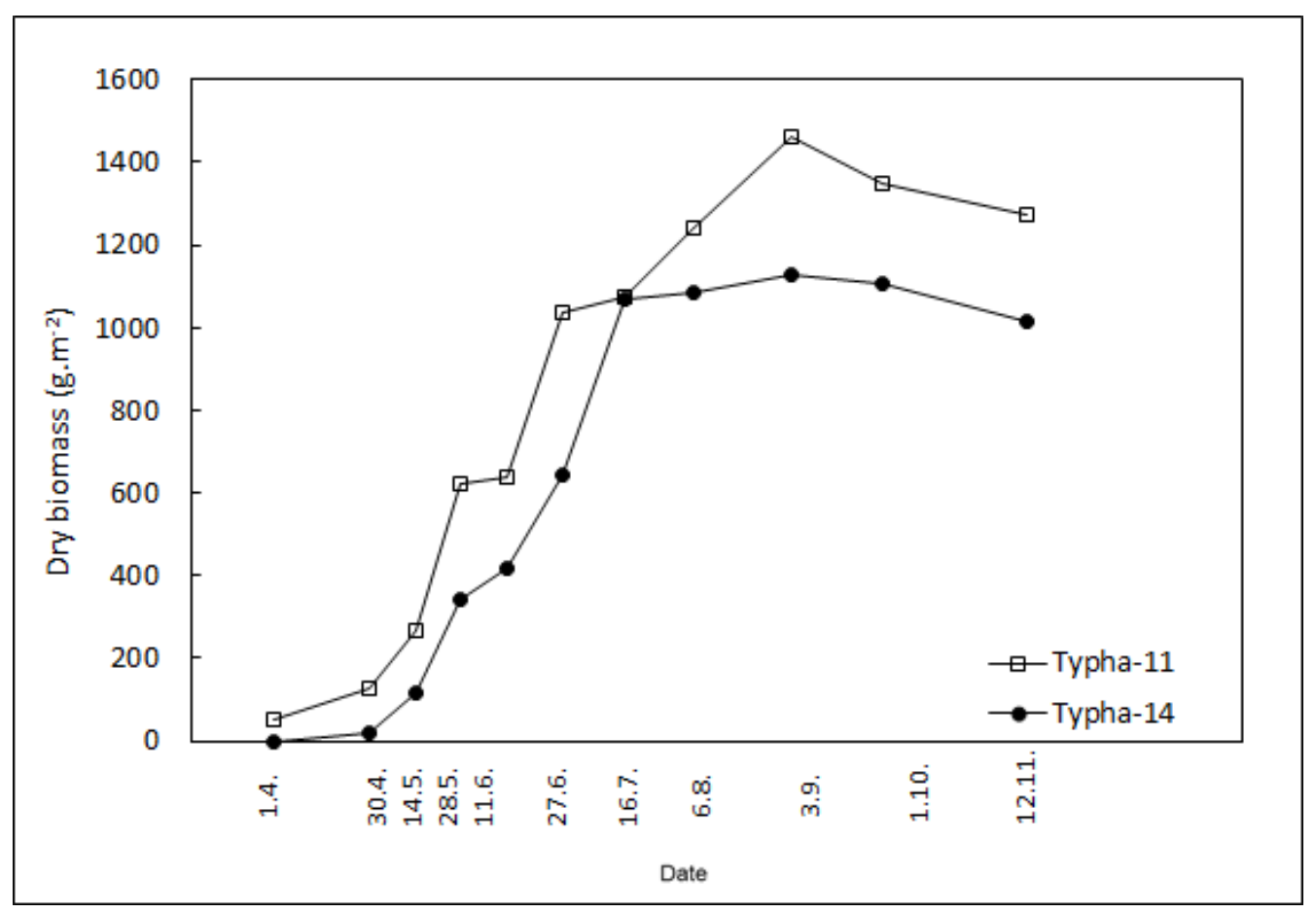

Figure 6. Dry biomass production of the Typha reed bed community

The biomass curves of unmanaged wet Cirsium and Filipendula meadows (Fig. 7) show an interesting similar trend between the Filip-13 and Cirs-16 stands which also reached the maximum values on the same date in August $\left(1,248 \mathrm{~g} \mathrm{DW}^{*} \mathrm{~m}^{-2}\right.$ at the Filip13 stand, $922 \mathrm{~g} \mathrm{DW}^{*} \mathrm{~m}^{-2}$ at the Cirs-16 stand), then significantly declined. The Filip-1 stand had a different development - after a rapid increase between May and mid-June there were no dramatic changes in values. The maximum $\left(1,172 \mathrm{~g} \mathrm{DW}^{*} \mathrm{~m}^{-2}\right)$ was reached in July.

The curves for managed (mowed) meadows of various types (Fig. 8) show many similarities in their development. In general, the first mowing (between 11 and 27 June) was obviously done after the first period of the post-peak decline; all the maximum values were reached at the end of May except for the Cirs-2 stand (11 June, $380 \mathrm{~g}$ $\mathrm{DW}^{*} \mathrm{~m}^{-2}$ ). Surprisingly, the highest biomass value was not observed in the intensively managed and nutrient-rich stand of the IntensM-8 class $\left(540 \mathrm{~g} \mathrm{DW}^{*} \mathrm{~m}^{-2}\right)$ but in the Alop-3 stand (577 g DW* $\mathrm{m}^{-2}$ ). The Alop-18 and Arrhen-20 stands had lower peak values (471 and $389 \mathrm{~g} \mathrm{DW}^{*} \mathrm{~m}^{-2}$ respectively).

The second peak was reached in August in all cases. All the locations except the Alop-18 were mown just before the sampling date of the $3^{\text {rd }}$ September; the Alop-18 stand had not been mown until the $5^{\text {th }}$ September. The highest values of the second peak occurred at the Cirs-2 stand (361 $\left.\mathrm{g} \mathrm{DW}^{*} \mathrm{~m}^{-2}\right)$, which is comparable to the first peak 
value. The biggest difference was observed in the Alop-18 stand (by approx. $350 \mathrm{~g}$ $\mathrm{DW}^{*} \mathrm{~m}^{-2}$ ). Other locations show an even decline between the first and the second mowing by approx. $150-200 \mathrm{~g} \mathrm{DW}^{*} \mathrm{~m}^{-2}$.

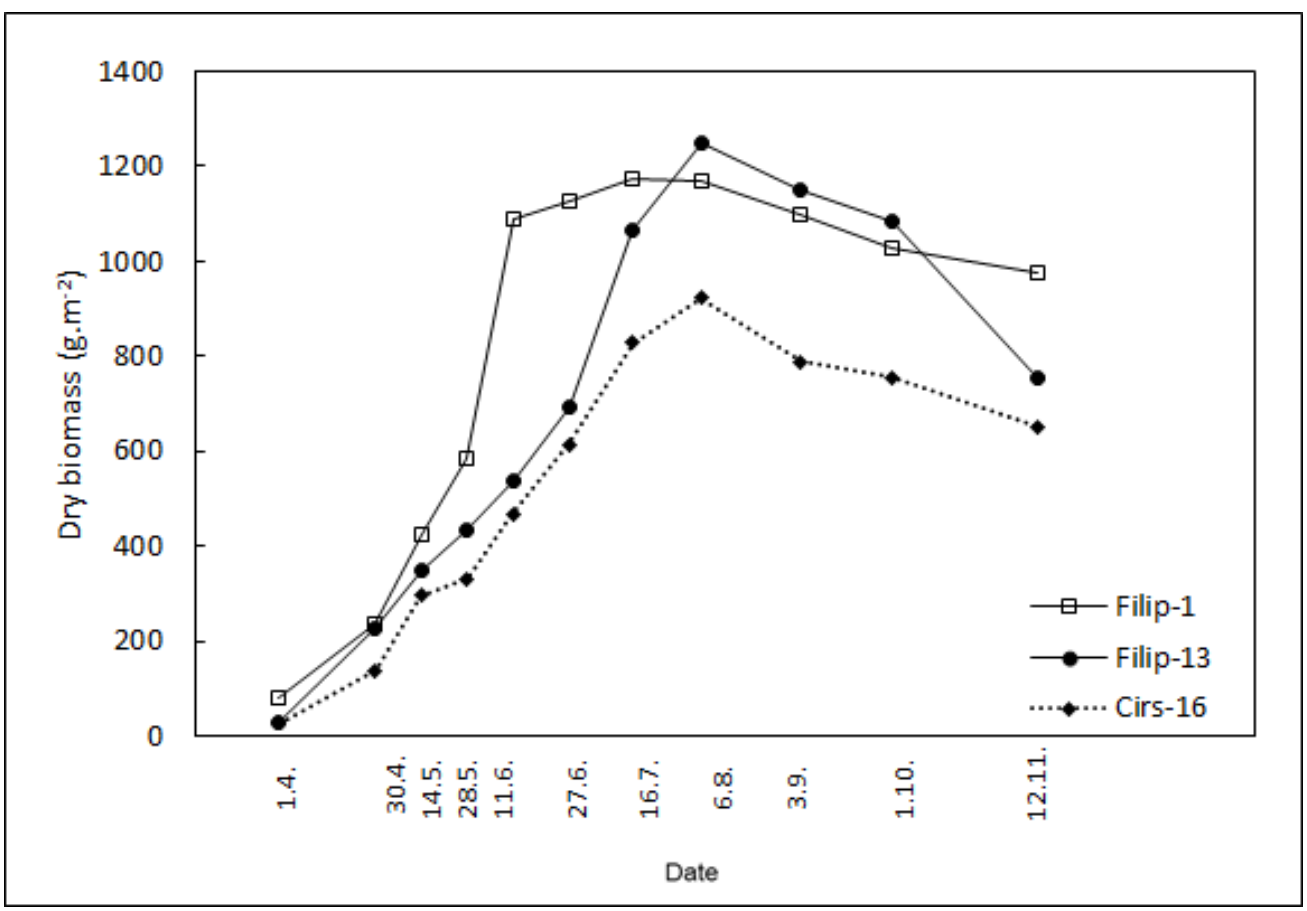

Figure 7. Dry biomass production of unmanaged wet meadows

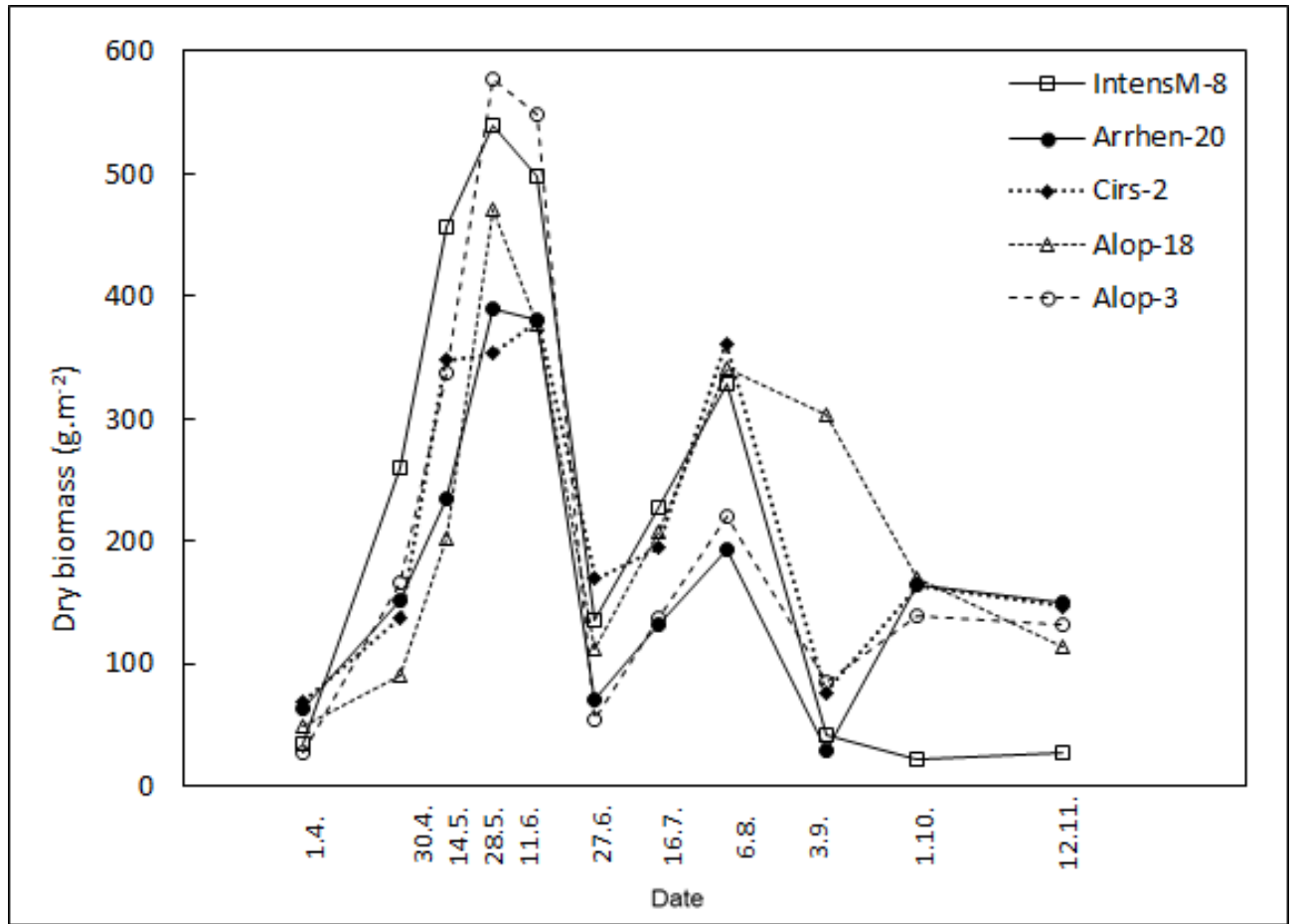

Figure 8. Dry biomass production of mowed meadows 
The Arrhen-20, Cirs-2 and Alop-3 stands also formed the third peak in October; the biomass amount was relatively even on these localities $\left(165,164\right.$, and $140 \mathrm{~g} \mathrm{DW}^{*} \mathrm{~m}^{-2}$ respectively). The continuing decline of the IntensM- 8 curve is caused by autumn grazing.

Biomass curves of crops (Fig. 9) differ significantly both as to their trends and values.

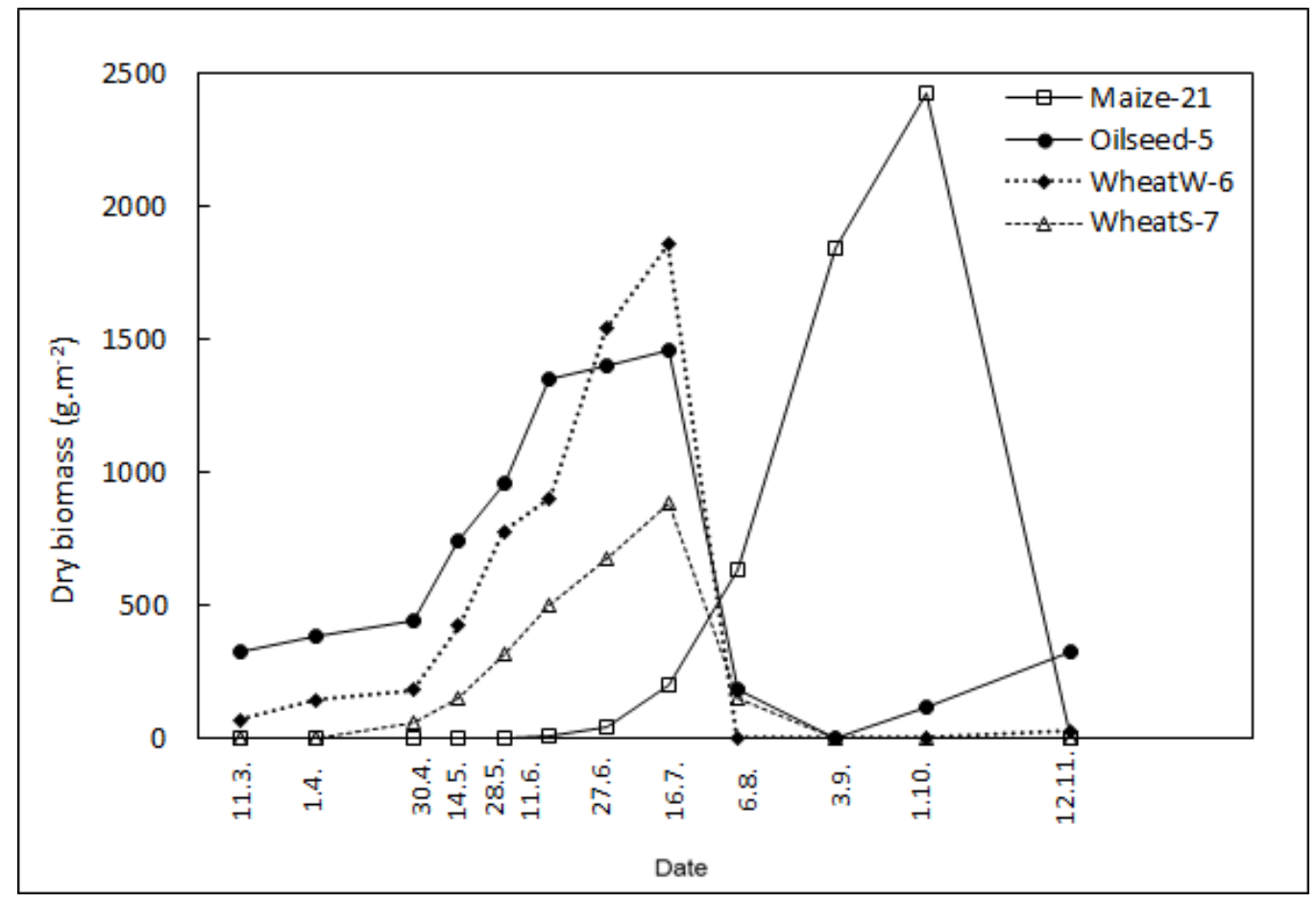

Figure 9. Dry biomass production of agricultural crops

Table 2. Average values of average biomass values ( $\left.g D W^{*} m-2\right)$ of all stands in all sampling terms.

\begin{tabular}{|c|c|c|c|c|c|c|c|c|c|c|c|c|}
\hline & 11.3.2013 & 1.4.2013 & 30.4 .2013 & \begin{tabular}{|l|}
14.5 .2013 \\
\end{tabular} & 28.5.2013 & \begin{tabular}{|l|}
11.6 .2013 \\
\end{tabular} & 27.6.2013 & \begin{tabular}{|l|}
16.7 .2013 \\
\end{tabular} & 6.8.2013 & 3.9 .2013 & \begin{tabular}{|l|}
1.10 .2013 \\
\end{tabular} & 12.11.2013 \\
\hline ReedL-9 & 0,0 & 47.7 & 282.8 & 793.6 & $1,334.4$ & $1,487.0$ & $1,953.8$ & $1,964.9$ & $1,980.0$ & $2,291.8$ & $2,308.7$ & $1,162.5$ \\
\hline ReedT-4 & 0.0 & 5.8 & 36.1 & 248.0 & 579.0 & 836.9 & $1,009.3$ & $1,222.5$ & $1,560.0$ & $1,628.7$ & $1,819.2$ & $1,256.0$ \\
\hline ReedT-19 & 0.0 & 0.0 & 48.4 & 116.4 & 252.3 & 427.8 & 669.5 & $1,133.8$ & $1,334.5$ & $1,460.8$ & $1,543.6$ & $1,480.4$ \\
\hline Typha-11 & 0.0 & 52.7 & 108.0 & 269.4 & 621.4 & 636.6 & $1,038.2$ & $1,076.7$ & $1,242.6$ & $1,460.8$ & $1,346.2$ & $1,275.5$ \\
\hline Typha-14 & 0.0 & 0.0 & 21.4 & 116.1 & 341.9 & 420.1 & 641.1 & $1,068.6$ & $1,085.8$ & $1,128.6$ & $1,107.7$ & $1,016.0$ \\
\hline Glyc-10 & 0.0 & 139.4 & 168.0 & 287.6 & 464.2 & 527.0 & 674.8 & 940.3 & 859.2 & 890.4 & 853.0 & 591.7 \\
\hline Glyc-17 & 0.0 & 58.6 & 218.5 & 376.3 & 726.2 & 753.3 & $1,036.7$ & $1,291.1$ & $1,216.2$ & $1,141.2$ & $1,094.8$ & $1,053.1$ \\
\hline Carex-12 & 0.0 & 30.7 & 126.8 & 367.2 & 699.3 & 795.5 & 970.2 & 847.3 & 815.2 & 811.3 & 781.2 & 772.7 \\
\hline Carex-15 & 0.0 & 66.3 & 166.3 & 314.5 & 540.8 & 596.3 & 893.3 & 947.5 & 963.3 & 831.4 & 759.7 & 06.2 \\
\hline Filip-1 & 0.0 & 78.6 & 237.6 & 423.3 & 584.0 & $1,087.2$ & $1,125.8$ & $1,172.4$ & $1,167.8$ & $1,096.6$ & $1,025.3$ & 972.9 \\
\hline Filip-13 & 0.0 & 29.1 & 226.4 & 349.3 & 431.3 & 538.1 & 691.5 & $1,066.8$ & $1,247.6$ & $1,151.5$ & $1,081.7$ & 754.9 \\
\hline Cirs-16 & 0.0 & 26.8 & 138.3 & 295.3 & 330.2 & 466.5 & 614.1 & 827.4 & 922.2 & 786.8 & 55.5 & 650.9 \\
\hline Cirs-2 & 0.0 & 69.1 & 138.0 & 347.4 & 353.7 & 379.8 & 169.0 & 194.3 & 361.1 & 76.2 & 163.9 & 147.0 \\
\hline Alop-3 & 0.0 & 27.2 & 166.3 & 338.1 & 576.9 & 548.2 & 53.9 & 137.1 & 219.8 & 85.4 & 39.7 & 131.1 \\
\hline Alop-18 & 0.0 & 49.7 & 91.2 & 202.1 & 470.6 & 376.7 & 112.8 & 207.6 & 340.6 & 303.8 & 69.7 & 114.0 \\
\hline Arrhen-20 & 0.0 & 63.6 & 152.3 & 234.4 & 389.4 & 380.7 & 70.5 & 131.7 & 192.5 & 29.7 & 164.9 & 150.4 \\
\hline IntensM-8 & 0.0 & 33.7 & 260.0 & 457.2 & 540.0 & 497.8 & 136.3 & 228.0 & 327.6 & 40.9 & 21.8 & 27.2 \\
\hline Maize-21 & 0.0 & 0.0 & 0.0 & 0.0 & 1.9 & 2.7 & 38.8 & 201.2 & 636.5 & $1,840.2$ & $2,429.7$ & 0.0 \\
\hline Oilseed-5 & 324.6 & 380.1 & 439.4 & 739.1 & 956.7 & $1,349.4$ & 1.401 .3 & $1,457.8$ & 180.9 & 0.0 & 115.3 & 324.6 \\
\hline WheatW-6 & 65.3 & 140.5 & 181.0 & 423.5 & 778.4 & 902.4 & $1,538.8$ & $1,856.3$ & 0.0 & 0.0 & 0.0 & 25.2 \\
\hline WheatS-7 & 0.0 & 0.0 & 58.2 & 151.3 & 312.0 & 500.6 & 678.1 & 878.9 & 144.7 & 0.0 & 0.0 & 0.0 \\
\hline
\end{tabular}

The Maize-21 curve shows a rapid increase between July and October and the maximum value was reached in this late period just before the harvest $\left(2,430 \mathrm{~g} \mathrm{DW}^{*} \mathrm{~m}^{-}\right.$ 
${ }^{2}$ ). The Oilseed-5 curve evenly increases until the harvest time in July (the maximum value is $\left.1,458 \mathrm{~g} \mathrm{DW}^{*} \mathrm{~m}^{-2}\right)$; since it was grown as a winter crop, the curve declines after harvest ( $6^{\text {th }}$ August), then falls to zero ( ${ }^{\text {rd }}$ September - ploughing) and slowly increases again in the autumn. The wheat curves, interestingly, have a different development - the WheatW-6 curve shows more similarities with the oilseed biomass growth and reaches even a higher maximum value $\left(1,505 \mathrm{~g} \mathrm{DW}^{*} \mathrm{~m}^{-2}\right)$ before the harvest, then it declines and only in November a slight increase could be observed. The WheatS-7 spring wheat curve increases slowly and evenly until the pre-harvest maximum also in July, which is only almost a half of the winter crop peak value $\left(817 \mathrm{~g} \mathrm{DW}^{*} \mathrm{~m}^{-2}\right)$. It was possible to capture the biomass value of stubble in August $\left(145 \mathrm{~g} \mathrm{DW}^{*} \mathrm{~m}^{-2}\right)$, then the field was ploughed.

\section{Discussion}

\section{Discussion on methodology}

The methodical approach of this study was defined to balance three factors - the needs of the above mentioned research project, representativeness of the samples and obtained data, and the possibility and requirements of the biomass sampling procedure and processing.

The studied biotope types present representative samples of non-forest landscape elements in the Emergency Planning Zone; they cover $51 \%$ of the non-forest area of the zone (34.1\% of the total area of the zone) (Vinciková et al., 2010). The sampling locations were selected as typical stands of their type (Chytrý et al., 2010) in the studied catchments which were chosen as the sample areas of the project; nevertheless, it would be more accurate to sample at least five stands of each biotope to cover the nutrient, moisture and other variability of the environment and its impact on the biotope. This method would be of course much more demanding and time-consuming (sampling must be carried out on the same date) and it is generally applied for detailed studies of one or a few biotope types (e.g. Kaplová et al., 2011).

Similar limits defined the sampling method itself. Three sampling points is the minimum number to acquire representative data (Dykyjová, 1989), five samples present a good enhancement of the representativeness; situating the sampling points along (in most cases) the moisture transect helped cover the diversity of the stands even better. Also the sampling dates were chosen in sufficient intervals, covering more precisely the estimated peaks of the biomass amount than the end of the season. This approach is very important especially in case of wetland communities, with a rapid growth in the first half of the vegetation season such as the Phragmites stands (e.g. Ćížková et al., 2001; Dykyjová and Květ, 1970).

The procedure of sampling the plots and further biomass processing was carried out according to the standard methodology (Dykyjová, 1989; Ondok and Květ, 1978; Květ and Westlake, 1998).

\section{Discussion on results}

The results of the biomass production sampling are generally difficult to compare with other authors regardless the fact the methods used are identical, because the conditions of the stands vary both in space and time. They are influenced especially by nutrient and water supply depending on the micro-, meso- and also macroclimate of the 
area. Comparing the biomass values of the same plot sampled during two different growing seasons can be a bit tricky as well because of the differences in the yearly distribution of precipitation, temperatures and sunny days; spring temperatures and water availability are especially important (Květ and Westlake, 1998). The season of sampling was significant for its very wet springtime and relative lack of precipitation in the second half of the year (cf. Fig. 2). In the following text the comparison of measured and reviewed biomass values was done mostly by comparing the trends of the production curves, where available, rather than focusing on the individual values. Especially in case of the rich-in-species stands the variability of values can be higher than in monocultures; that is why we provide a detailed description of the species composition of the stands both in Tab. 1 and in the text to explain the occurring differences.

\section{Reed beds of eutrophic still waters dominated by the Phragmites australis}

The first shoots of the ReedL-9 littoral reed community appeared in March and an intensive growth was observed until the end of June; the maximum $\left(2,309 \mathrm{~g} \mathrm{DW}^{*} \mathrm{~m}^{-2}\right)$ was reached at the beginning of October (Fig. 3). The shape of the growth curve is comparable to the results of Dykyjová and Hradecká (1976) from the Opatovice pond situated in the Třeboň region, South Bohemia, although the maximum was reached there in September and the value was lower $\left(1,824 \mathrm{~g} \mathrm{DW}^{*} \mathrm{~m}^{-2}\right)$. Květ and Westlake (1998) published the Phragmites growth curves measured in South Moravia (Czech Republic), England and Denmark. These curves followed a similar trend, only the curve from South Moravia increased faster than the other curves, situated in colder areas. Our ReedL-9 littoral stand best corresponds with the curve from Moravia whereas the terrestrial reeds of the ReedT-4 and namely ReedT-19 stands, with their slower increase in spring, rather resemble the English production curve.

Significantly more information was found on the maximum reached values of the biomass of the Phragmites stands. Dykyjová and Květ (1970) stated maximum biomass values of eleven South-Bohemian and six South-Moravian fishponds (both locations to be found in the Czech Republic) sampled between 1965 and 1969. They ranged from 890 to $2,730 \mathrm{~g} \mathrm{DW}^{*} \mathrm{~m}^{-2}$ (littoral stands of South Bohemia) and from 865 to $1,930 \mathrm{~g}$ $\mathrm{DW}^{*} \mathrm{~m}^{-2}$ at terrestrial stands in Moravia. This reflects the variability of biomass production; warmer Moravian locations also reached their maximum up to 1.5 month earlier than the South Bohemian fishponds. Květ and Husák (1978) mention the range of the aboveground biomass between 600 and 3,500 $\mathrm{g} \mathrm{DW}^{*} \mathrm{~m}^{-2}$. In her study on the Phragmites biomass production in Estonia Ksenofontová (1988) measured the peak biomass values between 668 and $1,311 \mathrm{~g} \mathrm{DW}^{*} \mathrm{~m}^{-2}$. Our measured maximum values correspond well with these data. The later maximum values $\left(1^{\text {st }}\right.$ October 2013$)$ could have been caused either by the site conditions or the sampling year climate course but are by no means unique - Dykyjová and Květ (1970) measured the peak value as late as $9^{\text {th }}$ October 1966.

\section{Reed beds of eutrophic still waters dominated by the Typha angustifolia}

Květ and Westlake (1970) published the growth curves of the Typha angustifolia observed in various regions of the Czech Republic. Initially its increase was less steep than that of the Phragmites curves, which was confirmed in our locations as well. The Typha-11 curve trend, maximum value and date are in line with these data (Květ and 
Westlake, 1998). Dykyjová and Květ (1970) presented the maximum values measured in littoral stands of the Opatovice fishpond in South Bohemia in August and September, ranging from 1,570 to $3,880 \mathrm{~g} \mathrm{DW}^{*} \mathrm{~m}^{-2}$. Květ and Husák (1978) provided similar results $\left(1,000-3,000 \mathrm{~g} \mathrm{DW}^{*} \mathrm{~m}^{-2}\right)$. Our maximum values $\left(1,461\right.$ and $1,129 \mathrm{~g} \mathrm{DW} \mathrm{DW}^{-2}$ respectively) correspond with the published results; nevertheless, the range of maximum values is again relatively wide.

\section{Reed beds of eutrophic still waters dominated by the Glyceria maxima}

The Glyc-10 and Glyc-17 growth curves, especially the increasing part until the June maximum, entirely correspond with the results published by Petrík (1972). The maximum values were identically measured in June and are fairly similar $(1,090$ measured by Petŕík, our results are 940 and $1,291 \mathrm{~g} \mathrm{DW}^{*} \mathrm{~m}^{-2}$ respectively). The decrease of our curves is rather slower. The curves published by Květ and Westlake (1998) from the Czech Republic and England are similar except that the spring increase occured later and the maximum values were reached in September and October. Again, this can be caused by yearly weather development, general climatic conditions of the area and stand conditions. Květ and Westlake (1998) provided a low maximum stand crop $\left(600-1,100 \mathrm{~g} \mathrm{DW}^{*} \mathrm{~m}^{-2}\right)$ in the mild climate and relatively poor soil conditions of the English location; also the peak is relatively broad, because while old shoots are dying new shoots are emerging from July to September. In the more extreme climate and fertile soils of the Czech Republic the maximum standing crop is higher $(1,200-$ $3,200 \mathrm{~g} \mathrm{DW}^{*} \mathrm{~m}^{-2}$ ) and the peak is much more distinct. The growth strategy of the Glyceria maxima is different from the Phragmites and Typha, some of the green shoots overwinter and increases rapidly in the spring and new shoots grow later. This is also influenced by the maturity of the stand.

As to the maximum values, Květ and Husák (1978) state a range between 600 and 2,600 $\mathrm{g} \mathrm{DW}^{*} \mathrm{~m}^{-2}$, Dykyjová and Květ (1970) measured $652 \mathrm{~g} \mathrm{DW}^{*} \mathrm{~m}^{-2}$ at the alluvial pond of the Dyje river (South Moravia) and 1,387 at a South Bohemian fishpond.

\section{Tall-sedge beds}

The growth curves of these stands (Fig. 5) are very similar until June. The Carex-15 curve continues increasing until August and falls down relatively quickly afterwards. A similar trend was published by Květ and Westlake (1978) for a Carex rostrata stand in Minnesota. The Carex-12 curve is more similar to the growth curve described by Novák (1977) who also noted an even growth until the June peak followed by a slow decline. Květ and Westlake state the maximum value for the Carex rostrata biomass reaching $700 \mathrm{~g} \mathrm{DW}^{*} \mathrm{~m}-2$; Prach et al. (1996) measured $940 \mathrm{~g} \mathrm{DW} * \mathrm{~m}-2$ in the C. acuta stand in the river Lužnice alluvium, which is very similar to our results (Tab. 2). Lukavská (1988) stated the maximum biomass between 627 and 1,059 g DW*m-2 for a vegetation community dominated by the $C$. acuta and accompanied by the Calamagrostis canescens and other Carex species which was reached in August. Also Kuncová (2009) measured the total maximum biomass of this community of Wet Meadows in Třeboň (South Bohemia, Czech Republic) corresponding to 546 or $670 \mathrm{~g} \mathrm{DW} * \mathrm{~m}-2$ respectively where the proportion of the C. acuta was 423 and 618 g. Novák (1970) stated the maximum total biomass of a similar community of $644 \mathrm{~g}$ where the $C$. acuta biomass only reached $248 \mathrm{~g}$. 


\section{Meadow communities rich in species}

A few studies were found focusing on the aboveground biomass production of the rich-in-species meadow vegetation communities. Their high variability poses difficulties when comparing the different stands: there were not many analogies to be found in literature especially for the unmanaged meadows of the Filip-1, Filip-13 and Cirs-16 classes. Prach et al. (1996) stated a maximum standing crop value for the stand dominated by the Filipendula ulmaria of 1,009 $\mathrm{g}$ in July, which is only slightly lower than our values.

The growth curves of the studied mown meadow stands are quite similar, characteristic by a steep increase until the first mowing (Fig. 8). The growth of grassland until the second mowing was less intensive and the maximum values reached approximately from one to two thirds of the first peaks. The maximum values especially before the first mowing were influenced by the stand type, especially its nutrient richness and water availability.

Petrrík (1970) observed a biomass growth in the Continental inundated meadows and Intermittently wet Molinia meadows in South Moravia during three years. The seasons differed more in terms of the maximum values than the curve trends which were quite similar and are well comparable with our curves.

\section{Crops on arable land}

We sampled the crop species that are most common in the studied area nowadays. Only the production of the crop parts which are then used (i.e. grain, straw, tuber or seed) is important enough to measure so it is practically impossible to find relevant data on the total aboveground production of any crop stands. Bureš (1970) observed the growth of oats and the maximum biomass he provides is $890 \mathrm{~g} \mathrm{DW}^{*} \mathrm{~m}^{-2}$; this value and the curve trend is analogous to our values for spring wheat. In case of silage corn, which is harvested as a whole, the yield values of various hybrids ranged from 1,400 to 2,050 $\mathrm{g} \mathrm{DW}^{*} \mathrm{~m}^{-2}$ (cf. http://www.zea.cz/). Our measured values are higher due to different cropping practices - whereas we harvested the biomass just above the ground, the harvest machines leave stubble of approx. $30 \mathrm{~cm}$ in height.

Surprising was the high production of biomass of winter wheat which far exceeded the seemingly richer production of oilseed. Facing the scarcity of relevant and comparable data in published papers we performed another sampling of both spring and winter wheat and oilseed crops in the estimated peak period of the 2014 vegetation season. Both the values were higher than the peak values of $2013\left(2,612 \mathrm{~g} \mathrm{DW}^{*} \mathrm{~m}^{-2}\right.$ for wheat and $1,921 \mathrm{~g} \mathrm{DW}^{*} \mathrm{~m}^{-2}$ for oilseed) which was probably caused by better growth conditions in 2014 but their ratio was almost identical (56 to 44\% in 2013 and 58 to $42 \%$ in 2014). This can be understood as an example of a high year-to-year variability of the aboveground biomass production. On the other hand, it means the ratios could serve for comparing the production curves for different seasons and it is a certain proof that the methodological approach we used was correct and suitable.

\section{Conclusion}

The paper summarizes the results of the annual biomass production measurement for many different biotopes and vegetation stands. It is generally not common to study biomass production of such wide variety of biotopes, especially when it comes to the 
stands with high species diversity such as various meadow types; this paper can therefore be used as a reference material for similar vegetation stands. This was also the reason why we provided a detailed description of species composition and abundance of the stands.

The results are compared with literature in cases where the values of adequate stands were available and the measured and reviewed values and/or curve trends were in almost all cases similar. This also supports the credibility of our results for the stands where no comparable data was found during our review.

The outputs of this study will be used in the above mentioned project to model the total amount of biomass which could be potentially contaminated by a radiation leak. Such an event can occur anytime in the year so the estimation of a momentary biomass production of the vegetation stands prevailing in the Temelín NPP Emergency Planning Zone is necessary. Nevertheless, the data can be used in an even broader sense - for the purposes of an estimate of biomass production as a source of renewable energy, observation of carbon balance and nutrient supplement, etc. Another important aspect can be the contribution of these data to broad-scale biomass production models, which are usually based on satellite imaging and often lack the direct in-situ calibration of the computed values.

Acknowledgements. The publication is supported by the research project of the Ministry of the Interior of the Czech Republic "Minimization of Radioactive Contamination Impacts on the Landscape in the Emergency Planning Zone of the Temelín Nuclear Power Plant". The authors also owe their thanks to their colleagues from the Laboratory of Applied Ecology for their effort put into biomass sampling and processing.

\section{REFERENCES}

[1] Aosaar, J., Varik, M., Lohmus, K., Ostonen, I., Becker, H., Uri, V. (2013): Long-term study of above- and below-ground biomass production in relation to nitrogen and carbon accumulation dynamics in a grey alder (Alnusincana (L.) Moench) plantation on former agricultural land - European Journal of Forest Research 132:737-749.

[2] Bentsen, N.S., Felby, C., Thorsen, B.J. (2014): Agricultural residue production and potentials for energy and materials services -Progress in Energy and Combustion Science 40:59-73.

[3] Bréda, N.J.J. (2003): Ground-based measurements of leaf area index: a review of methods, instruments and current controversies - Journal of Experimental Botany 54:2403-2417.

[4] Brom, J., Procházka, J., Nedbal, V., Vinciková, H. (2013): A GIS tool for early spatial assessment of radioactive contamination of agricultural crops and soil. In: Bezpecnost Jaderne Energie, v. 21(1-2), ISSN 1210-7085, Jan-Feb 2013, p. 48-52, International conference '34. radiation protection days' [in Czech].

[5] Bureš, F. (1970): The formation of yield in oats in the fodder crops rotation. In. Hejný S. et al. (1970): Productivity of terrestrial ecosystems, production processes. PT-PP report No 1 (1964-1969), Czechoslovak academy of sciences, 27p.

[6] Čížková, H., Pechar, L., Husák, S., Květ, J., Bauer, V., Radová, J., Edwards, K. (2001): Chemical characteristics of soils and pore waters of three wetland sites dominated by Phragmites australis: relation to vegetation composition and reed performance - Aquatic Botany 69:235-249. 
[7] Chytrý, M., Kučera, T., Kočí, M., Grulich, V., Lustyk, P. (eds.) (2010): Katalog biotopů České republiky. [Cataloque of biotopes of Czech Republic]. Ed. 2, AOPK ČR, Praha [in Czech].

[8] Cook, B.D., Bolstad, P.V., Naesset, E., Anderson, R.S., Garrigues, S., Morisette, J.T., Nickeson, J., Davis, K.J. (2009): Using LiDAR and quickbird data to model plant production and quantify uncertainties associated with wetland detection and land cover generalizations - Remote Sensing of Environment 113:2366-2379.

[9] Dykyjová, D. (1989): Metody studia ekosystémů. [Methodology of ecosystem studies].Academia, Praha, [in Czech].

[10] Dykyjová, D., Hradecká, D. (1976): Production Ecology of Phragmites communis 1. Relations of Two Ecotypes to the Microclimate and Nutrient Conditions of Habitat Folia Geobotanica and Phytotaxonomica 11: 23-61.

[11] Dykyjová, D., Květ, J. (1970): Comparisson of biomass production in reedswamp communities growing in South Bohemia and South Moravia. - In: Hejný S. et al. (1970): Productivity of terrestiral ecosystems, production processes. PT-PP report No 1 (19641969), Czechoslovak academy of sciences, 71-80.

[12] Heggenstaller, A.H., Liebman, M., Anex, R.P. (2009): Growth Analysis of Biomass Production in Sole-Crop and Double-Crop Corn Systems - Crop Science 49:2215-2224.

[13] Hejný, S. (ed.) (1970): Productivity of terrestrial ecosystems, production processes. PTPP report No 1 (1964-1969), Czechoslovak academy of sciences, 27p.

[14] Kaplová, M., Edwards, K.R., Květ, J. (2011): The effect of nutrient level on plant structure and production in a wet grassland: a field study. Plant Ecology. 212:809-819.

[15] Ksenofontová, T. (1988): Morphology, Production and Mineral Contents in Phragmites australis in Different Waterbodies of the Estonian SSR - Folia Geobotanica at Phytotaxonomica 23: 17-43.

[16] Kuncová, Š. (2009): Aboveground production of a wet meadow stand dominated by Carex acuta. Diploma thesis, University of South Bohemia in České Budějovice [in Czech].

[17] Květ, J., Husák, Š. (1978): Primary Data on Biomass and Production Estimates in Typical Stands of Fishponds Littoral Plant Communities. In: Dykyjová, D., Květ, J. (eds.): Pond Littoral Ecosystems. Structure and Functioning. Ecological Studies 28, Berlin: SpringerVerlag, 211-216.

[18] Květ, J., Westlake, D. F. (1998): Primary production in wetlands. - In: Westlake, D. F., Květ, J., Szczepanski, A. (eds.) The Production Ecology of Wetlands. Cambridge Uiversity Press, UK, 78-168.

[19] Lukavská, J. (1988): Vliv seče na produkční charakteristiky mokřadních travinných porostů. [Influence of mowing on the production parameters of the wtland grass communities.]. Diploma thesis, Vysoká škola zemědělská Praha, Fakulta agronomická v Českých Budějovicích, 944 pp. [in Czech].

[20] Moise, E.R., Henry, H.A. (2012): Interactions of herbivore exclusion with warming and $\mathrm{N}$ addition in a grass-dominated temperate old field - Oecologia 169:1127-1136.

[21] Mooney, H.A. (1991): Biological responses to global change: anagenda for research Ecol.Appl. 1:112-7.

[22] Moravec, J. (1994): Fytocenologie - nauka o vegetaci. [Phytocenology - studium on vegetation].Academia, Praha [in Czech].

[23] Na, Z., Guirui, Y., Zhenliang, Y., Shidong, Z. (2003): Simulation of leaf area index and biomass at landscape scale - Journal of Geographical Sciences 13:139-152.

[24] Novák, Z. (1977): Produktivita ostřicových společenstev na Mokrých loukách u Třeboně v závislosti na mikroklimatu. [Productivity of tall sedges on the Mokré louky site near Třeboň]. Diploma thesis. Pedagogická fakulta v Českých Budějovicích. 37 pp. [in Czech]. 
[25] Ondok, J. P, Dykyjová, D. (1973): Assessment of dominant reed-beds intheTřeboň basin. Methodical aspects. - In: Hejny, S. (ed.) Ecosystem study onWetland Biome in Czechoslovakia. Czechosl. IBP/PT-PP Report No 3, Třeboň 1973, p: 79-82.

[26] Ondok, J. P.,Květ, J. (1978): Selection of sampling areas in assessment of production. In: Dykyjová, D.,Květ, J. (eds.): Pond Littoral Ecosystems.Structure and Functioning, p. 163-174. Springer Verlag, Berlin.

[27] Palmer, A.R., Yunusa, I.A.M. (2011): Biomass production, evapotranspiration and water use efficiency of arid rangelands in the Northern Cape, South Africa - Journal of Arid Environments 75:1223-1227.

[28] Petř́k, B. (1972): Seasonal changes in plant biomass in four inundated meadow communities. In: Rychnovská, M. (ed.): Ecosystem study on grassland biome in Czechoslovakia, PT-PP/IPB, Report 2, Brno, pp. 17-23.

[29] Prach, K., Jeník, J., Large, A.R.G. (1996): Floodplain ecology and management. The Lužnice River in the Třeboň Biosphere Reserve, Central Europe. SPB Academic Publishing bv, The Netherlands, $285 \mathrm{pp}$.

[30] Rosef, L., Bonesmo, H. (2005): Seasonal variation in productivity in semi-natural grasslands - Acta Agriculturae Scandinavica Section B-Soil and Plant Science 55:36-43.

[31] Rychnovská, M. (ed.) (1987): Metody studia travinných ekosystémů. [Methodology of grassland ecosystem studies].Academia, Praha, 269 pp [in Czech].

[32] Scurlock, J.M.O., Johnson, K., Olson, R.J. (2002): Estimating net primary productivity from grassland biomass dynamics measurements. Global Change Biology. 8:736-753.

[33] Vinciková, H., Procházka, J., Brom, J. (2010): Timely identification of agricultural crops in the Temelín NPP vicinity using satellite data in the event of radiation contamination Journal of Agrobiology 27(2): 73-83.

[34] Wiegand, T., Snyman, H.A., Kellner, K., Paruelo, J.M. (2004): Do Grasslands Have a Memory: Modeling Phytomass Production of a Semiarid South African Grassland Ecosystems 7:243-258.

\section{APPENDIX}

Electronic Appendix: Photographic documentation of the studied sites 